\title{
Z badań nad operacjami majątkowymi w średniowiecznym Krakowie
}

\section{Wstęp}

Cytelnika średniowiecznych krakowskich ksiąg ławniczych zaskakuje liczebność zapisek informujących o operacjach majątkowych dokonywanych w ówczesnym Krakowie.

$\mathrm{Z}$ pewnością zjawisko to - występujące $\mathrm{z}$ takim natężeniem - zasługuje na uwagę badacza, zwłaszcza że dotąd nie zostało ono w pełni opracowane. Bogdan Lesiński swe bardzo cenne studium poświęcił jednej formie dyspozycji majątkowych, mianowicie kupnu renty ${ }^{1}$. Krystyna Bukowska zajęła się z dobrym skutkiem procesami o nieruchomości, lecz w epoce późniejszej (XVI-XVIII w.)². Temat zatem czeka na gruntowne opracowanie, czym piszący ma zamiar zająć się w przyszłości, tu ograniczając się do naszkicowania zarysu problematyki.

\section{Podstawa źródłowa}

Za podstawę źródłową przyjęliśmy roczne wycinki czasowe zapisów w dwóch księgach ławniczych krakowskich i jednej kazimierskiej, wychodząc z założenia, że niezależnie od administracyjnej odmienności Kraków i Kazimierz tworzą całość3. Pominęliśmy krakowską księgę wójtow-

${ }^{1}$ B. Lesiński, Kupno renty w średniowiecznej Polsce, Poznań 1966.

${ }^{2}$ K. Bukowska, Orzecznictwo krakowskich sadów wyższych w sporach o nieruchomości miejskie (XVI-XVIII w.), Warszawa 1967.

${ }^{3}$ Księgi ławnicze krakowskie z lat 1300-1375 opublikowane przez F. Piekosińskiego i J. Szujskiego pt. Liber actorum, resignationum nec non ordinationum civitatis Cracoviensis 13001375, [w:] Monumenta Medii Aevi Historica Res Gestas Poloniae Illustrantia, t. IV, Kraków 1878, s. 1-207, w skrócie Liber act. Crac.; Księgi ławnicze krakowskie 1365-1376, 1390-1397, 
ską z roku 1442, ponieważ jest w niej niewiele informacji o operacjach majątkowych, poza licznymi informacjami o zastawie ruchomości ${ }^{4}$.

Z Liber act. Crac. wykorzystujemy zapiski z roku 1328;

Z Krak. ławn. wykorzystujemy zapiski z roku 1396;

Z Kazim. ławn. wykorzystujemy zapiski z roku 1427.

Wybieraliśmy te lata, w których liczba zapisów jest znaczna ${ }^{5}$. Ponadto chcieliśmy mieć wgląd w występowanie operacji majątkowych w dłuższym przedziale czasowym.

\section{Zasób informacji}

Informacje o operacjach majątkowych mają postać oświadczeń pozbywcy lub jego pełnomocnika ${ }^{6}$ o wzdaniu (resignacio), czyli o zrzeczeniu się przezeń na rzecz nabywcy swych praw do pozbywanej rzeczy.

Liber act. Crac. 902 z 1328 r. signavit".

„Item Johannes Pistor dictus Pauline unum quartale Nicolao Rutheno re-

Bogatsze $\mathrm{w}$ treść są informacje o innych rodzajach operacji majątkowych, np. o zastawie, o zapisach na wypadek śmierci. Jest ich jednak niewielka liczba ${ }^{7}$.

\section{Kto pozbywa1}

Zdecydowanie dominują miejscowi mieszczanie. Obcy pojawiają się rzadko, przy czym nie zawsze da się stwierdzić, czy np. Johannes de Brega jest mieszkańcem Brzegu, czy tylko stamtąd pochodzi. Obawa znika, gdy ktoś jest określony jako civis np. Lemburgensis ${ }^{8}$.

wydał S. Krzyżanowski, Kraków 1964, w skrócie Krak. ławn.; Księgi ławnicze kazimierskie 1407-1427, wydała B. Wyrozumska, Kraków 1996, w skrócie Kazim. ławn.

${ }^{4}$ Księga wójtowska krakowska 1442-1443. Ze zbiorów Archiwum Państwowego w Krakowie przygotowali do druku M. Niwiński, K. Jelonek-Litewka, A. Litewka, Kraków 1995, w skrócie Krak. wójt.

${ }^{5} \mathrm{Z}$ tym jest różnie. Liczba wpisów w poszczególnych latach jest bardzo zróżnicowana.

${ }^{6} \mathrm{~Np}$. Kazim. ławn. 3226, 3229 z 1427 r. (tu pełnomocnik oświadcza, że ma pełnomocnictwo od pozbywcy do dokonania wzdania).

${ }^{7}$ Zob. pkt 6. Rodzaje operacji majatkowych.

${ }^{8}$ Np. Krak. ławn. 2304 z 1396 r.: "Cristoforus Vogil et domina Barbara conthoralis ipsius recognoverunt publice Johanni Boythom civi Ellemburgensi et Nicolao de Teich civi gleyviczensi... obligari". 
Sporadycznie jako pozbywcy występują miasto ${ }^{9}$, szlachta ${ }^{10}$, duchowieństwo ${ }^{11}$, Żydzi ${ }^{12}$. Jest jedna informacja, w której wójt dokonuje wzdania placu na polecenie króla. Skłonni jesteśmy jednak widzieć w tym raczej interwencję monarchy niż alienację jego dóbr ${ }^{13}$.

Pozbywcy bywali pojedynczy lub zbiorowi. W Liber act. Crac. w roku 1328 mniej więcej w równej liczbie są jedni i drudzy, przy czym często zbywają mąż z żoną ${ }^{14}$. W Krak. ławn. zdecydowanie występują pojedynczy, natomiast w Kazim. ławn. przeważają pozbywcy zbiorowi, głównie pozbywca z członkami rodziny.

Także gdy idzie o kobiety jako pozbywczynie są różnice między poszczególnymi księgami. W Liber act. Crac. występują one zwykle bez opiekuna, niezależnie od stanu cywilnego ${ }^{15}$. W Krak. ławn. w roku 1396 kobiety w charakterze zbywców występują stosunkowo rzadko, lecz zazwyczaj same, bez opiekuna ${ }^{16}$. W Kazim. ławn. w roku 1427 w ogólnej liczbie 24 informacji o operacjach majątkowych, kobiety zbywają nieruchomości w sześciu przypadkach, w tym w pięciu przy udziale opiekunów ${ }^{17}$.

O zbywaniu nieruchomości nieletnich, poza jednym przypadkiem, źródła milczą ${ }^{18}$.

${ }^{9}$ Krak. ławn. 2360 z 1396 r.: „Andreas Wirzing et Johannes Piczczin nomine consilii civitatis Cracovie domum dicte civitatis in plathea Hospitalis circa Polakonem, domine Nicolai Folmer conthorali legittime resignaverunt et promiserunt". Także 2369 z t.r.

${ }^{10}$ Liber act. Crac. 906, 917, 958, 993 z 1328 r.

${ }^{11}$ Liber act. Crac. 934, 943, 970, 988 z 1328 r.

${ }^{12}$ Liber act. Crac. 996 z 1328 r.

${ }^{13}$ Liber act. Crac. 971 z 1328 r.: "Stasco advocatus de mandato domini Regis Johanni filio Hulizlai, aream, que iacet in platea s. Crucis... iure hereditario resignavit". W zapisce następnej, 972, tenże Jan ów plac wzdał dwu nabywcom.

${ }^{14}$ W Liber act. Crac. 969 z 1328 r. kilku pozbywców wzdaje jednemu nabywcy różne nieruchomości.

${ }^{15}$ Np. Liber act. Crac. 984 z 1328 r. mężatka wzdaje pół kramu. W zap. 992 wzdaje mężowi część jatki (quartale maccelli). W zapisce 947 „domina Katherina relicta Mauricii cum suo filio... et Hedvigi filia sua et cum omni progenie et tota posteritate sua, quartale unum in platea Vizle Nicolao dicto Rutheno iure hereditario resignavit cum fundo tenendam et habendam..."

${ }^{16}$ Np. Krak. ławn. 2222, 2265, 2273, 2350, 2367 i in. z 1396 r.

${ }^{17}$ Kazim. ławn. 3172, 322, 3227, 3237, 3244.

18 Liber act. Crac. 995 z 1328 r. Dwaj opiekunowie nieletnich wzdają „virtel mediam curiam", niewątpliwie należącą do nieletnich. W Kazim. ławn. 3210 z 1427 r. 9-letni syn pozbywcy wyraża zgodę na sprzedaż przez ojca pół łanu i domu. Wójt, przewodniczący ławy, tę zgodę przyjął i zaakceptował. 


\section{Kto nabywał}

W Liber act. Crac. dominują obcy, to jest nabywcy niespokrewnieni $\mathrm{z}$ pozbywca, $\mathrm{i}$ to $\mathrm{z}$ reguły osoby pojedyncze. Jest trochę operacji między bliskimi ${ }^{19}$. Rzadko występują kobiety ${ }^{20}$.

W Krak. ławn. w roku 1396 obserwujemy ten sam stan rzeczy. W zapiskach kazimierskich z roku 1427 nabywcami są przeważnie całe rodziny, mąż, żona i dzieci, ewentualnie wszyscy spadkobiercy ${ }^{21}$. Wydaje się, że te różnice trzeba tłumaczyć stosowaniem przez pisarzy różnych formularzy.

Często nabywcą jest sąsiad zbywającego ${ }^{22}$.

\section{Rodzaje operacji majątkowych}

\begin{tabular}{|c|c|c|c|c|c|c|c|c|c|c|c|}
\hline \multirow[b]{2}{*}{ Źródła } & \multirow[b]{2}{*}{$\begin{array}{c}\text { Zapisek } \\
\text { ogółem }\end{array}$} & \multicolumn{10}{|c|}{ Zapiski z dyspozycjami majątkowymi } \\
\hline & & 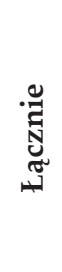 & 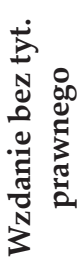 & 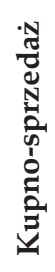 & 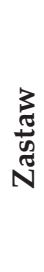 & 丞 & 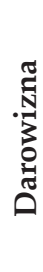 & 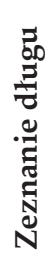 & 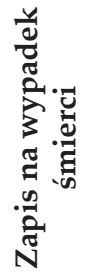 & 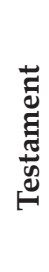 & 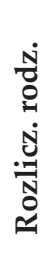 \\
\hline 1 & 2 & 3 & 4 & 5 & 6 & 7 & 8 & 9 & 10 & 11 & 12 \\
\hline $\begin{array}{l}\text { Liber act. } \\
\text { Crac } 1328\end{array}$ & 100 & 96 & 87 & - & - & 1 & - & - & - & - & 8 \\
\hline $\begin{array}{c}\text { Krak. } \\
\text { ławn. } 1396\end{array}$ & 162 & 150 & 89 & 4 & 9 & 7 & 1 & 8 & 12 & 3 & 17 \\
\hline $\begin{array}{c}\text { Kazim. } \\
\text { ławn. } 1427\end{array}$ & 115 & 24 & 12 & 1 & 1 & - & 1 & - & 6 & 1 & 2 \\
\hline
\end{tabular}

Źródło: oprac. własne.

${ }^{19} \mathrm{~Np}$. transakcje między braćmi - Liber act. Crac. 949, 982, między dziećmi a matka, zap. 923, pasierbicą a macochą - zap. 955, mężem a żoną - zap. 956, 992. Wszystkie zapiski $\mathrm{z}$ roku 1328.

${ }^{20}$ Kobieta o nieznanym stanie cywilnym - zap. 906, 917, mężatka - zap. 909, wdowa - zap. 905.

${ }^{21}$ Kazim. ławn. np. 3170, 3176, 3178 i szereg innych.

${ }^{22}$ Krak. ławn. 2242, 2286, 2292, 2343. 
Jak wynika z powyższego zestawienia, oba źródła krakowskie są właściwie rejestrami operacji majątkowych. Odstają od nich pod tym względem zapiski kazimierskie. $W$ nich wpisów generalnie jest mniej i proporcjonalnie mniej operacji majątkowych.

Przechodzimy obecnie do krótkiego omówienia poszczególnych rodzajów operacji majątkowych.

\subsection{Kupno-sprzedaż}

Umowa kupna-sprzedaży nie jest $\mathrm{w}$ księgach notowana. Terminy techniczne emere, vendere pojawiają się $\mathrm{w}$ nich sporadycznie, jako dodatkowe informacje, np. o pochodzeniu zbywanej nieruchomości ${ }^{23}$, lub element uprawnień nabywcy ${ }^{24}$.

Tylko $\mathrm{w}$ pojedynczych przypadkach wzdanie jest expressis verbis połączone ze sprzedażą ${ }^{25}$. Niemal zawsze brak jest informacji, jaki był tytuł prawny wzdania. Jednakże bez większego ryzyka można uznać, że wzdanie nastąpiło w wyniku kupna-sprzedaży. Przemawiają za tym wyliczane przy okazji wzdania uprawnienia nabywcy, charakterystyczne dla właściciela ${ }^{26}$. Gwoli ścisłości trzeba jednak zaznaczyć, że w zapiskach krakowskich z 1396 r. tej wyliczanki uprawnień nabywcy brak, jest samo resignavit, resignaverunt i na tym kończy się tekst zapiski ${ }^{27}$.

Poza wzmianka, że pozbywca oświadcza, że wzdał, nic o samym wzdaniu źródła nie mówią. Można sądzić, że miało ono postać oświadczenia składanego w sądzie przez pozbywcę lub osobę przezeń upoważniona, w którym zrzekał się on na rzecz nabywcy swych praw do pozbywanej nieruchomości, ściślej prawa własności. Źródła nie wspominają czy wzdanie było ujęte $\mathrm{w}$ jakieś sformalizowane formułki bądź ge-

${ }^{23}$ Np. Krak. ławn. 2385 z 1396. W zap. 2296 z 1396 r. „in contractu empcionis et vendicionis", lecz bez treści kontraktu.

${ }^{24} \mathrm{~Np}$. Kazim. ławn. 3227 z 1427 r.: ",temporibus perpetuis habendam, vendendam et in usus beneplacitos convertendam".

${ }^{25}$ Np. Krak. ławn. 2307 z 1396 r.: „recognovit publice, quod penu stans in braseatorio, per ipsos [syna i matkę] vendito et resignato”. Kazim. ławn. 3226 z 1427 r.: „Anna H. statuit Sigismundum [był wójtem] in tutorem pro resignacione domus, quam dicta H. Cunrado vendidit muratori".

${ }^{26}$ Liber act. Crac. 900 z 1328 r.: „iure hereditario resignaverunt”. Zap. 948: „iure hereditario resignavit possidenda et habenda”. Kazim. ławn. 3228 z 1427 r.: „habendam et vendendam et in usus beneplacitos convertendam". Warto jednak odnotować, że powszechność umów kupna-sprzedaży sprawiała, iż terminem technicznym emptio-venditio określano też inne formy operacji majątkowych. Zwraca na to uwagę K. Bukowska, Orzecznictwo..., s. 55.

${ }^{27}$ Krak. ławn. 2322 z 1396 r.: „Bartko sutor domum suam... resignavit et promisit” i szereg innych. 
sty $^{28}$. Nie ujawniają też ceny kupna ${ }^{29}$. Czasem o cenie można dowiedzieć się z ubocznej informacji, gdy np. podana jest kwota, w której nabywca zastawia sprzedawcy nabytą odeń nieruchomośćc ${ }^{30}$, lub kwota długu nabywcy wobec pozbywcy ${ }^{31}$.

Wwiązanie pojawia się $\mathrm{w}$ księgach bardzo rzadko, bez związku z aktem kupna-sprzedaży, jako element postępowania egzekucyjnego na mocy decyzji sądu ${ }^{32}$.

\subsection{Pozostałe rodzaje dyspozycji}

Inne rodzaje dyspozycji majątkowych występują rzadko i niewiele o nich da się powiedzieć. Zastaw nieruchomości, popularny w prawie ziemskim ${ }^{33}$, w Krakowie występuje sporadycznie. Nie pojawia się przy tym $\mathrm{w}$ postaci umowy zastawu, lecz jako zobowiązanie dłużnika, że w razie niedotrzymania warunków płatności będzie odpowiadał częścią lub całością majątku ${ }^{34}$. Nie miejsce tu na ustalanie charakteru prawnego tej sytuacji. Gdy idzie o prawo ziemskie, zdania są podzielone ${ }^{35}$.

${ }^{28} \mathrm{~K}$. Bukowska pisze, że wyznaczano starszego ławnika jako pełnomocnika sprzedawcy w celu dokonania wzdania, ale jako dowód powołuje jednak glosę I do Zwierciadła Saskiego. W badanych przez nas księgach sądowych brak potwierdzenia tej informacji.

${ }^{29} \mathrm{~K}$. Bukowska przytacza opinię krakowskiego sądu wyższego z połowy wieku XVII, że dawniej często nie notowano ceny nabycia. K. Bukowska, Orzecznictwo..., s. 55.

${ }^{30}$ Krak. ławn. 2273 z 1396 r. nabytą jatkę nabywca zastawia pozbywcy w kwocie 9 grzywien groszy. W zap. 2316 z t.r. nabywca zastawia nabyty dom (wzdany mu przez pozbywcę w zap. 2315) w kwocie 73 i pół grzywny groszy praskich. O tym zob. K. Bukowska, Orzecznictwo..., s. 56

${ }^{31}$ Np. Kazim. ławn 3176 i 3177 z 1427 r. - 30 grzywien, 3203 z t.r. - 50 grzywien $\mathrm{w}$ trzech ratach.

${ }^{32}$ Kazim. ławn. 3185, 3244, 3248 z 1427 r. O różnych koncepcjach co do istoty wwiązania zob. K. Bukowska, Orzecznictwo..., s. 21 i nast. Na s. 56 wspomina o przeniesieniu posiadania, lecz terminu wwiązanie nie stosuje. Polemicznie do wywodów Autorki odniósł się piszący te słowa $\mathrm{w}$ artykule recenzyjnym pt. Z zagadnień rozwoju miejskiego prawa prywatnego w Polsce, CPH, 1969, t. XXI, z. 2, s. 209 i nast.

${ }^{33}$ Zob. J. S. Matuszewski, Zastaw nieruchomości w polskim prawie ziemskim do końca XV wieku, AUL, ZNUŁ, Nauki Humanistyczno-Społeczne, Folia Iuridica, ser. I [Łódź], 1979, nr 53.

${ }^{34}$ Zastaw domu - Krak. ławn. 2220, zastaw całości majątku - 2245.

${ }^{35} \mathrm{Z}$ faktu, że zobowiązanie „sub obligacione omnium bonorum” obejmowało cały majątek dłużnika, także ten, który będzie miał w przyszłości, każe taką obligacio zaliczyć do zobowiązań. W obrębie prawa ziemskiego czyni tak J. Matuszewski, Zastaw..., s. 43. Recenzując tę pracę B. Lesiński postulował poszukiwanie dalszych argumentów przemawiających za taką klasyfikacją. B. Lesiński, O prawnych formach kredytu w Polsce średniowiecznej, CPH, 1980, t. XXXII, z. 2, s. 191. Postulat ze wszech miar słuszny, winien być traktowany jako dezyderat dla badacza zastawu nieruchomości $\mathrm{w}$ miastach polskiego średniowiecza. 
Spotykamy dwukrotnie następującą sytuację: nabywca nabytą nieruchomość zastawia pozbywcy. Sądzimy, że czyni tak, ponieważ nie ma pieniędzy na zapłacenie ceny kupna ${ }^{36}$.

Zapisy na wypadek śmierci były dokonywane głównie przez mężczyzn. W trzech przypadkach zapis był czyniony na rzecz żony, żony z dziećmi, w związku z planowaną pielgrzymką do Rzymu ${ }^{37}$. Czasem brak informacji o pielgrzymce, a zapis jest czasowy: usque ad adventum (nie wiadomo skąd) ${ }^{38}$. Niekiedy są to zapisy wzajemne małżonków ${ }^{39}$.

\subsection{Obowiązek zastępu}

Mamy następującą sytuację:

W Liber act. Crac. obowiązek zastępu nie jest notowany. W Krak. ławn. każdemu wzdaniu towarzyszy zobowiązanie do zastępu ${ }^{40}$. W Kazim. ławn. brak wzmianki o zastępie. Niewątpliwie zobowiązanie do zastępu wynikało z mocy prawa ${ }^{41}$, a różnice $\mathrm{w}$ księgach można tłumaczyć stosowaniem przez pisarzy różnych formularzy. Pod terminem promittere kryje się czasem co innego niż obowiązek zastąpienia nabywcy w razie niepokojenia przez osoby trzecie w związku z dokonanym aktem kupna-sprzedaży. Na przykład w Krak. ławn. 2270 z 1396 r. pozbywca promisit stawić w sądzie brata i dzieci, by wyrazili zgodę na alienację.

Obowiązek zastępu bywał niekiedy zabezpieczony zastawem całego majątku ${ }^{42}$. Mógł go przejąć na siebie kto inny, np. brat pozbywcy ${ }^{43}$.

\section{Przyczyny dokonywania operacji majątkowych}

Gdy idzie o kupno-sprzedaż, w oświadczeniach o wzdaniu sprzedanej nieruchomości nie ma informacji, co skłoniło pozbywcę do alienacji. W przypadku nabywców niekiedy można mniemać, że powięk-

\footnotetext{
${ }^{36}$ Krak. ławn. 2273, 2316 z 1396 r.

${ }^{37}$ Kazim. ławn. 3169, 3172, 3185 z 1427 r.

${ }^{38}$ Krak. ławn. 2225 z 1396 r.

${ }^{39}$ Kazim. ławn. 3172, 3195, 3217 z 1427 r.

${ }^{40}$ Np. zap. 2221 z 1396 r. - „resignavit et promisit”, czasem „resignavit etc.”, np. zap. 2223 z t.r.

${ }^{41}$ Krak. ławn. 2245 z 1396 r.: "et promisit sub obligacione omnium hereditatum suarum secundum ius etc."

${ }^{42}$ Zob. wyżej, przyp. 41.

${ }^{43}$ Np. Krak. ławn. 2284 z 1396 r.: ,"et promisit Petrus frater suus pro impedimento”.
} 
szają oni swą majętność, gdy np. skupują kilka nieruchomości ${ }^{44}$. Tym też kierowali się sąsiedzi pozbywcy, nabywając sprzedawaną przezeń nieruchomośćc ${ }^{45}$.

Wydaje się, że działali w Krakowie zawodowi handlarze nieruchomości, co jednak wymaga operowania całym materiałem znajdującym się w księgach, a nie wycinkami czasowymi ${ }^{46}$.

\section{Przedmiot operacji majątkowych}

Przedmiotem operacji majątkowych były różne części składowe majątku pozbywcy: dom ${ }^{47}$, dom cum fundo ${ }^{48}$ lub stojący na cudzym gruncie ${ }^{49}$, dom z ogrodem ${ }^{50}$, części domu ${ }^{51}$, ogrody ${ }^{52}$, place, kramy, słodowniki czy piwiarnie, łaźnie, młyny ${ }^{53}$.

${ }^{44}$ Np. Liber act. Crac. 907-911, 937-941, 947, 969. Także 919, 929, 967, 990 (nabywca Mikołaj Wierzynek). W 969 kilku pozbywców sprzedaje jednemu nabywcy różne dobra. Wszystkie tu powołane zapiski pochodzą z roku 1328.

${ }^{45}$ Zob. wyżej pkt 4 Kto nabywat.

${ }^{46}$ Dla przykładu: w Liber act. Crac. 902 z 1328 r. „Iohannes pistor dictus Pauline unum quartale Nicolao Rutheno resignavit". Tenże Jan w następnej zapisce 903 nabywa od Tylusa "unum quartale in plathea Sutorum".

${ }^{47} \mathrm{~Np}$. Krak. ławn. 1737 z 1396 r. i szereg innych. W Liber act. Crac. zwykle pod nazwą curia, np. zap. 915. W zap. 904 czytamy: „media curia, scilicet domus lapidea”.

${ }^{48}$ Liber act. Crac. 991 z 1328 r. - „media curia cum fundo”, także zap. 994, 995. „Braseatorium cum fundo" w zap. 942, "quartale cum fundo" w zap. 964.

${ }^{49}$ Np. Krak. ławn. 2212 z 1396 r.: „Mauritius Weigil edificia sua in plathea Hospitalis... stancia in fundo pauperum hospitalis... Johanni Czepelin resignavit et promisit". Zob. też zap. 2257, 2344. Zob. również, co pisze w związku z tym o zasadzie „superficies solo cedit" i sporach co do jej obowiązywania w prawie saskim K. Bukowska, Orzecznictwo..., s. 33 .

${ }^{50}$ Np. Kazim. ławn. 3170 z 1427 r. W Liber act. Crac. pojawia się często określenie „domus et hereditas", np. w zap. 3228.

${ }^{51}$ Części domu - Liber act. Crac. 900 z 1328 r.: „duas partes curie”, 901: „,media curia”. Kazim. ławn. 3196 z 1427 r.: „,sue porcionis domus”. Krak. ławn. 2266 z 1396 r.: „medietatem suam domus”. Czasem zbywana część jest niezbyt dokładnie określona: „plus quam $1 / 2$ curiam in latitudine", Liber act. Crac. 960 z 1328 r.

${ }^{52}$ Liber act. Crac. 951 z 1328 r.

${ }^{53}$ Jatki, np. Liber act. Crac. 969 z 1328 r., kramy (instita) - Krak. ławn. 2252 z 1396 r., piekarnie - Liber act. Crac. 908 z 1328 r. (tres banedos pani), słodowniki lub piwiarnie (braseatorium) - Liber act. Crac. 912 z 1328 r., łaźnie - Krak. ławn. 2221 z 1396 r., młyny - Krak. ławn. 2406 z 1396 r. 
Domy nie miały numeracji. Ich położenie określano podając plac, przy którym stały, sąsiadów ${ }^{54}$. Nie wiemy, co oznacza często stosowany w Liber act. Crac. termin quartale ${ }^{55}$, np. quartale maccelli ${ }^{56}$, curie $^{57}$, virtel mediam curiam $^{58}$.

\subsection{Pochodzenie alienowanych nieruchomości}

Czasem pozbywca podaje, że pozbywaną nieruchomość nabył drogą spadku po ojcu ${ }^{59}$, kupił za pieniądze ojca ${ }^{60}$, własne ${ }^{61}$ lub sam wybudował ${ }^{62}$.

\section{Stanowisko bliskich wobec alienacji}

Nie wiemy, czemu służyło podkreślanie, że alienowana nieruchomość pochodzi ze spadku po ojcu lub że była nabyta za pieniądze ojca.

Służyło to być może zaznaczeniu jej „rodowego" charakteru. Natomiast informacja, że alienowane dobra były nabyte za pieniądze pozbywcy lub że pozbywca dom sam zbudował, mają antyretraktowy charakter.

Prawa bliskich do alienowanej „rodowej” nieruchomości, przynajmniej $\mathrm{w}$ prawie ziemskim, wynikały $\mathrm{z}$ członkostwa $\mathrm{w}$ niedziale albo z prawa bliższości krewnych. W przeciwieństwie do prawa ziemskiego, w którym niedział rodzinny i prawo bliższości krewnych zostały monograficznie opracowane ${ }^{63}$, dla prawa miejskiego takich badań brak.

W niniejszym artykule przytoczymy dowody na stanowisko bliskich wobec alienacji nieruchomości. Używamy określenia „bliskich” zamiast

${ }^{54}$ Np. Krak. ławn. 2215 z 1396 r.: „,in plathea Slawcoviensi, ex opposito ecclesie s. Marci”. Krak. ławn. 2212 z 1396 r.: „,circa domum Polak in plathea hospitalis”.

${ }^{55}$ Liber act. Crac. 902, 903 z 1328 r. i in.

${ }^{56}$ Liber act. Crac. 905 z 1328 r. - „vendidit quartale unius maccelli”.

${ }^{57}$ Liber act. Crac. 913 z 1328 r.: "tria quartalia curie cum domo lapidea”, zap. 917 - „tria quartalia”.

${ }^{58}$ Liber act. Crac. 995 z 1328 r.

${ }^{59}$ Liber act. Crac. 963 z 1328 r.; Kazim. ławn. 3212 z 1427 r.

${ }^{60}$ Liber act. Crac. 956 z 1328 r. W zap. 996 mąż (Żyd) wzdaje żonie dom kupiony za pieniądze jej ojca.

${ }^{61}$ Zob. s. 78 - pytanie do sądu, czy można alienować nieruchomość nabytą za własne pieniądze.

${ }^{62}$ Liber act. Crac. 962 z 1328 r.

${ }^{63} \mathrm{~B}$. Waldo, Niedział rodzinny w polskim prawie ziemskim do końca XV stulecia, Wrocław 1967; Z. Rymaszewski, Prawo bliższości krewnych w polskim prawie ziemskim do końca XV wieku, Wrocław 1970. 
„krewnych”, by uwzględnić także stanowisko żon czy wdów. Ich ewentualne uprawnienia wynikały z praw wiennych.

Badane źródła nie pozwalają na dokładniejsze ustalenie prawnego charakteru udziału krewnych przy alienacji. Poza wyżej podanymi przykładami występowania krewnych wśród pozbywców lub nabywców nieruchomości przez rodzinę ${ }^{64}$, spotykamy przypadki zgody na alienację $e^{65}$ bądź też sprzeciwu ${ }^{66}$.

\section{W którym sądzie należało składać oświadczenie o operacjach majątkowych}

Wydaje się, że sądem właściwym dla składania oświadczeń o operacjach majątkowych był sąd ławniczy. W Liber act. Crac. bardzo często wpis oświadczenia o wzdaniu rozpoczynają następujące zwroty: „Coram quo iudicio"67, „In eodem iudicio"68, „Coram predictis advocato et scabinis" ${ }^{\prime \prime 9}$. Nie występują one w Krak. ławn. ani w Kazim. ławn., lecz masowe wpisy oświadczeń o wzdaniu w księgach tych sądów wyraźnie wskazują że były one właściwe dla tych oświadczeń.

\section{Kontrola miasta}

Miasto strzegło swych interesów. W szczególnej sytuacji, gdy nabywcą był wrotny królowej, miasto wyraża zgodę na nabycie przezeń połowy domu pod warunkiem, że będzie ponosił wszelkie ciężary na rzecz miasta. Jeśli tego czynić nie będzie, wzdanie zostanie unieważnione ${ }^{70}$. Ponadto $\mathrm{w}$ jednym przypadku nastąpiło unieważnienie przez sąd wzdania, lecz

${ }^{64}$ Zob. wyżej, pkt. 4 i 5.

${ }^{65}$ Krak. ławn. 2290 z 1396 r. Dział majątku, potem uczestnik działu wzdaje to, co otrzymał (camera) osobie trzeciej za zgodą pozostałych uczestników działu.

${ }^{66}$ Np. Krak. ławn. 2373 z 1396 r.

${ }^{67} \mathrm{~Np}$. Liber act. Crac. 899 z $1328 \mathrm{r}$.

${ }^{68}$ Liber act. Crac. 914 z 1328 r.

${ }^{69}$ Liber act. Crac. 906 z 1328 r.

${ }^{70}$ Krak. ławn. 2266 z 1396 r.: „,quam resignacionem domini consules admiserunt tali modo, quod dictus L. et sui successores de dicta medietate domus omnia iura civilia facere debent, quod quandocunque per eum aut suos successores factum non fuerit, debet premissa resignacio nullius fore roboris vel momenti". 
przyczyn tej decyzji nie znamy ${ }^{71}$. Innym razem sąd odrzuca pretensje powoda pod adresem wzdania, jak się wydaje dlatego, że zostało dokonane we właściwym terminie ${ }^{72}$.

Inny charakter miała zgoda miasta na alienację nieruchomości.

Tu sytuacja nie pozostawała $\mathrm{w}$ związku $\mathrm{z}$ interesami miasta, a była następująca: noszący się z zamiarem alienacji zwracał się do sądu z pytaniem, czy może sprzedać nieruchomość, którą kupił lub wybudował własnym sumptem ${ }^{73}$. W rachubę zatem wchodziły dobra nabyte i bodaj z powodu tej cechy szczególnej sąd wyrażał zgodę na sprzedaż. Rola sądu sprowadzała się tutaj do funkcji interpretatora prawa: sąd orzekał, że według prawa istnieje swoboda alienacji dóbr nabytych.

\section{Zakończenie}

Operacje majątkowe w średniowiecznym Krakowie to tematyka dla historyka prawa obszerna i interesująca. Pobieżne jej naszkicowanie w niniejszym przyczynku wskazuje niezbicie, że zasługuje ona na szczegółowe opracowanie. $Z$ pewnością nie jest to zadanie łatwe, ale może przynieść nader interesujące wyniki, wszak to terra incognita.

\section{Bibliografia}

\section{Źródła}

Księgi ławnicze kazimierskie 1407-1427, wyd. B. Wyrozumska, Kraków 1996.

Księgi ławnicze krakowskie 1300-1375, wyd. F. Piekosiński i J. Szujski pt. Liber actorum, resignationum nec non ordinationum civitatis Cracoviensis 1300-1375, [w:] Monumenta Medii Aevi Historica Res Gestas Poloniae Illustrantia, t. IV, Kraków 1878.

Księgi ławnicze krakowskie 1365-1376, 1390-1397, wyd. S. Krzyżanowski, Kraków 1964.

Księga wójtowska krakowska 1442-1443, przygotowali do druku M. Niwiński, K. Jelonek-Litewka, A. Litewka, Kraków 1995.

${ }^{71}$ Krak. ławn. 2237 z 1396 r.: „Sentenciata est resignacio medietatis domus per Nicolaum Zolder Johanni Trepper facta nullius esse roboris nec momenti". W zap. 2226 położono areszt na wzdaniu połowy domu.

${ }^{72}$ Kazim. ławn. 3196 z roku 1396: „Resignacio, quam fecit Margaretha sue porcionis domus, eam concutere uxor Strosch non valet, quia facta est in tempore ligato".

${ }^{73}$ Krak. ławn. 2259, 2313 z 1396 r. 


\section{Opracowania}

Bukowska K., Orzecznictwo krakowskich sądów wyższych w sporach o nieruchomości miejskie (XVI-XVIII w.), Warszawa 1967.

Lesiński B., Kupno renty w średniowiecznej Polsce, Poznań 1966.

Lesiński B., O prawnych formach kredytu w Polsce średniowiecznej, CPH, 1980, t. XXXII, z. 2.

Matuszewski J. S., Zastaw nieruchomości w polskim prawie ziemskim do końca XV wieku, AUL, ZNUŁ, Nauki Humanistyczno-Społeczne, Folia Iuridica, ser. I [Łódź], 1979, nr 53.

Rymaszewski Z., Prawo bliższości krewnych w polskim prawie ziemskim do końca XV wieku, Wrocław 1970.

Rymaszewski Z., Z zagadnień rozwoju miejskiego prawa prywatnego w Polsce, CPH, 1969, t. XXI, z. 2.

Waldo B., Niedział rodzinny w polskim prawie ziemskim do końca XV stulecia, Wrocław 1967. 